\title{
How the British Helped in the Defence of Reims, May to July, 1918
}

\author{
Lieut.-Colonel A. L. St. Glyn
}

To cite this article: Lieut.-Colonel A. L. St. Glyn (1922) How the British Helped in the Defence of Reims, May to July, 1918, Royal United Services Institution. Journal, 67:467, 474-482, DOI: 10.1080/03071842209434665

To link to this article: http://dx.doi.org/10.1080/03071842209434665

册 Published online: 11 Sep 2009.

Submit your article to this journal $\widetilde{ }$

Џ Article views: 3

Q View related articles 5 


\section{HOW THE BRITISH HELPED IN THE DEFENCE OF REIMS, MAY TO JULY, 1918.}

By Iieut.-Colonel $A$. St. L. Glyn.

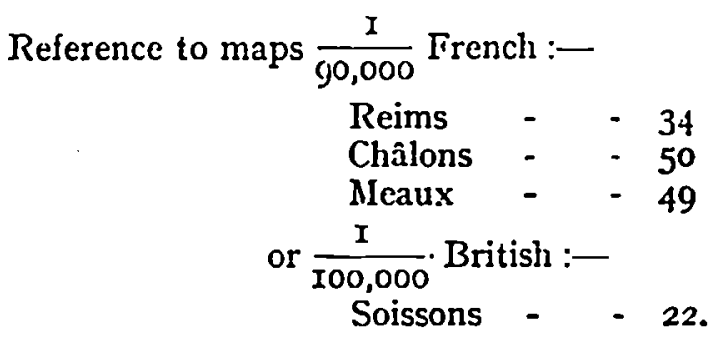

TO the valour of the troops of the Iieme Corps Colonial, and more

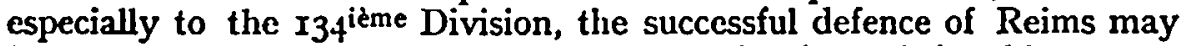
be ascribed; but, without in any way detracting from their achievement, it is quite patent that the British troops employed in the Groupe des Armées du Nord played a far from inconsiderable part in the ultimate success of this brilliant defence. And in order to demonstrate this I write the following short article, founded partly on personal observation but principally on documents to which, in my position as British Liaison Officer with the G.A.N., I have had access.

The story divides itself naturally into two parts: the attack of the 27th May and the attack of the I 5 th July.

In May, 19I8, two British Corps, with certain Divisions which had been heavily engaged in the two early spring German offensives of St. Quentin-Noyon in March, and Armentières-Ypres in April, were sent down to recuperate in the then quiet sector held by the G.A.N.

The VIIIth Corps, commanded by Lieut.-General Sir A. Hunter Weston, K.C.B., having the Igth Division, Major-General G. D. Jeffreys, C.B., C.MI.G., was in the IVieme Arméc. The Corps being at Châlons, where also was the headquarters of the IVième Armée and the Division in billets between that place and Vitry le François.

The IXth Corps, commanded by Lieut.-General Sir $A$. Hamilton Gordon, K.C.B., having the 8th Division, Major-General IV. C. G. Heneker, C.B., D.S.O., 21st Division, Major-General D. G. M. Campbell, C.B., 25th Division, Major-General Sir E. G. T. Baimbridge, K.C.B., and the 5oth Division Major-General H. C. Jackson, D.S.O., was in the VIieme Armée. This Corps had its H.Q. at Jonchéry-sur-Vesle, with three Divisions, the 5oth, 8th and 2Ist, in line, holding from Craonne on the 
cast of the Chemin des Dames heights to Cauroy south of the Aisne ; the 5oth and 8th Divisions were north of the river and the 2Ist Division south. The 25th Division was in Corps Reserve round Arcis le Ponsart.

The H.Q.s of the G.A.N. was at Avize; that of the VIieme Arméc at Soissons.

The VIieme Armée held the line from Varesnes, cast of Noyon, to the Canal de l'Aisne, immediately west of Reims, and the IViemc Armée carried on as far as St. Thomas immediately west of the Argonne.

The front held by these two armies was extremely highly organised, complete with second and third lines and many defensive switches. And the wire in front of each line was extremely formidable, and it was owing to the strength of the lines that these very severely tried Divisions were sent down to what was supposed to be a quict sector to reorganise. Unfortunately the strength was more apparent than real, for, in order to find a sufficient reserve in the northern areas, the Divisions in line were extremely extended, and the Divisions in reserve available for immediate action were very few.

On the morning of the 27th May the Germans brought off what must be considered as one of the most successful surprise attacks of the Great War. I can confidently say that it was only 24 hours before the attack was launched that the French High Command became acquainted with the designs of the Germans, and then only principally owing to the declarations of two prisoners taken during the late evening of the $25^{\text {th }}$ by the XIiemc Corps on the immediate left of the British Corps. I must, however, add that for several days the visibility had been poor and no reliable air reports had been received.

This attack was heralded by a very intense bombardment witl a high percentage of gas shells. The bombardment not only annihilated the front line, but covered many areas in rear as far back as Fismes and Jonchéry. Rather before dawn, and after only some four hours' bombardment, 3I German Divisions, of which 21 were fresh, attacked on a front of 33 miles from Leuilly to Courcy, the grcatest strength being between the Aisne and Vauxaillon, where $2 \mathrm{I}$ Divisions were employed, the general objective of the attack being the River Marne between Dormans and Vermeuil. The full force of this attack (2r Divisions) fell upon

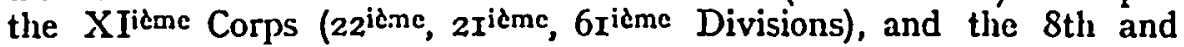
5oth British Divisions.

The success was immediate, for the Germans effected the crossing of the Aisne east of Vailly, which was the H.Q.S of the XIidme Corps, by mid-day the 27 th and reached the northern outskirts of Fismes by nightfall, thus cutting the communications between the VIicme Armée and the IXth Corps.

By the 29th the Germans held the eastern outskirts of Soissons, Fère en Tardenois and Tramery; and by the night of the 3oth Tigny;, the northern bank of the Marne between Brasles and Jauglonne and, further cast, Romigny. 
It will be noticed that the Germans attacked on a line south and slightly west, and consequently the rupture came between the XIieme Corps and the IXth Corps. The right of this latter was always firmly

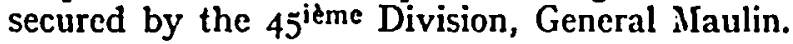

The 25th Division was thrown into the fight as three Brigades in support of the three Divisions in line, about I2 noon on the 27 th.

It was not until the 30 th that the Germans were finally held up on a line running from the Marne, north of Chattillon, south of Romigny and Ville en Tardenois, the Montagne de Bligny, Bligny, Pargny and Coulommes.

On the night of the 28th-29th the I9th Division was brought up , into the battle region in the Ardre Valley by motor lorry and relieved the hard-pressed remains of the IXth Corps during the 29th. All available effectives, consisting of some 2,000 rifles and 36 field guns, were left at the disposal of the G.O.C. Igth Division, and it was with these far from ample means that General Jeffreys was able to hold up the German attack in this region.

You will see, if you consult the map, the importance of the service here rendered. The Ardre runs north-west from the Montagne de Reims and joins the Vesle at Fismes; had the heights between Courmas and Coulommes been taken, it would have gone hard with the Montagne de Reims, and once the Montagne de Reims in German hands the fall of Reims was a matter of hours.

The IXth Corps having been taken out of the line, General Sir A. Hamilton Gorden did his utmost to assist the rgth Division by forming provisional battalions from details, reinforcements, and stragglers, and sending them up again to the battle in the Valley of the Ardrc. He also organised a small independent brigade, consisting of three battalions, each with a strength of about 400 men, and one MI.G. company from the remains of the 21st Division. This Brigade, under command of Brig.-General G. H. Gater, D.S.O., held the south bank of the Marne from Dormans to Mareuil le Port until relieved by the French about the IIth Junc. Neanwhile, the Igth Division, with the remnants of the IXth Corps, held the line in the Valley of the Ardre. The Germans made several attacks; in fact, on one occasion the Montagne de Bligny was lost, but it was retaken the same day by a successful counter attack. But the losses were extremely heavy during this period owing to the exposed situation of the troops.

On the r 8 th June the British troops under General Jeffreys were relieved by the IInd Italian Corps under General Allbricci, and shortly after returned to the British zone.

Up to the end of these operations the Germans employed in all 44 Divisions; II in the line on the 27th May being reinforced by 33 from general reserve. Thus ended what may be considered as the first phase of the defence of Reims.

The period from the middle of June to the I th $^{\text {th }}$ of July was com- 
paratively calm on the front of the G.A.N., although there were plenty of indications tending to show that another general German attack was imminent all along the line from west of Soissons to the Argonne, but more especially on the eastern front of the IVicme Arméc and west of Reims.

These indications were so patent owing to the cxcellence of visibility and information drawn from prisoners, that it was possible to make preparations to counter the attack.

The second portion of this story divides itself into two distinct operations, viz. :-

(a) The German attack on the Champagne (IVième Arméc) front which started on the r5th July, and in which no British troops were engaged.

(b) The German attack east of Reims in which the XXIInd Corps played a not inconsiderable part, and which started on the same day.

But in order to thoroughly understand these two operations it is necessary to give a short account of. the former first.

Acting under orders received from the French High Command the IVieme Arméc abandoned for several nights in succession its forward line of defence, thus giving up voluntarily many salient points which had been previously taken from the Germans at great cost. This line was daily reoccupied before dawn. On the night of the $I_{4}$ th- $5_{5}$ th July the IVieme Armée had for the fifth time abandoned its forward line and taken up the strongly entrenched second line some 3 miles in rear, an extremely heavy bombardment was opened about $x$ p.m. on the front (abandoned) line, and on localitics in rear as far back as Chatons. Owing to the excellence of the arrangements made by the French this bombardment caused little damage. In the grey of dawn the Germans attacked on a front of about 40 kilometres between the Fort de la Pompelle and Tahure with no less than 20 Divisions, carried the first line with ease and, according to time-table, continued the advance; but were met 3 miles in rear by the French in the extremely strong and well-wired second position. Owing to faulty communications and in presence of this totally unexpected turn of affairs the German Command was unable to discontinue the attack. Their troops, disposed in great depth, gradually closed up on their advanced lines, which were everywhere held up by the French.

They attempted by sheer weight of numbers to break through the line, but without avail. The battle continued all day, and at night the Germans, having suffered a loss which was estimated at 50 per cent. of the force engagcd, fell back on the original French first line, which they held on to.

The results of this battle were eminently successful. The French had put out of action, certainly for a considerable period, about one-tenth 
of the total German Divisions available on the IVestern Front, and had had to employ none of their reserve Divisions; but to accomplish this they had abandoned their original front line, which made their hold on Reims still more precarious.

On the same day, and at the same time, the Germans also attacked west of Reims, on a front of some 25 miles from east of Château Thierry to Vrigny, with I5 Divisions. Owing to the lines here being of a very temporary nature it was impossible to employ the tactics which were so successful with the IVicme Armée.

In the valley of the Ardre region, Coulommes, Courmas, Marfaux, Pourcy, and even Nanteuil la Fosse, which had been the H.Q.s of the rgth Division in June, were taken; the Bois de Courton also fell into German hands, and, further west, La Neuville, Belval and the Bois du Roi also.

They also effected the passage of the Mame, took Crezancy and the high ground round St. Agnan, la Chapelle, Comblizy, Festigny and Mareuil le Port.

A counter attack by U.S. troops on the 16 th inst. forced them out of Crezancy, but they continued to press eastwards along the Mlame towards Epernay, and made themselves masters of Baursault and Venteuil. The situation on the front of the Vieme Armée was distinctly disquieting between the I5th and the night of the I7th July.

On the 15th July the XXIInd Corps, commanded by Lieut.-General Sir A. J. Godley, K.C.B., K.C.M.G., consisting of the 5Ist Division, Major-General G. T. C. Carter Campbell, D.S.O., and 6and Division, Maj.-General Sir IV. P. Braithwaite, K.C.B., arrived in the back areas of the G.A.N., detraining in the region of Romilly sur Scine and Mailly le Camp. Owing to the gravity of affairs, this Corps was hurried forward by motor lorrics and was concentrated south-east of Epernay on the I 7 th, with H.Q.s at Vertus.

The general attack made by the G.A.R. on the I8th eased the situation in front of the Vieme $A$ rmée considerably, chiefly by diverting the German Divisions in immediate reserve; but the situation of Reims was still very critical.

It is now known from captured German documents that the objects of the German attacks on the I5th July were Châlons and the passages of the Marne about that place, coupled with the passage of the Marne east of Chateau Thierry, the scizure of the high ground round Montmort. and the attack of Epernay from the west. After which a vast right whecl was to be made pivoting on Château Thierry, and a march direct on Paris between the Scine and the Marne undertaken.

$\Lambda t$ all cost the Montagne de Reims had to be held. It was, therefore, decided that the XXIInd Corps was to relieve the IInd Italian Corps, which had been badly treated in the valley of the Ardre during the night of the Igth-2oth, and the Corps was to attack on the morning of the 2oth, with objectives Bois de Courton and Bois de Pourcy. 
As the British artillery could not come up in time the preparation was to be undertaken by all artillery, both French and Italian, that was in position. The 62nd Division was to attack on the east of the Ardre, and the 5Ist Division on the west. And so began the battle for the XXIInd Corps - a battle which the magnitude of the success of the G.A.R. and VIitne Armée has greatly obliterated.

For I2 days the Corps was in action continuously, and gradually drove back the enemy during that period until on relief the line ran west of La Neuville, west edge of Bois de l'Eglise, Montagne de Bligny, southern outskirts of Sarcy and Aubilly, and so continued by the French through St. Euphraise and Vrigny. Besides considerable material taken, 2 I officers and r, 139 other ranks were captured. But each Division suffered about 4,000 casualties.

This is a very short description of the work of the British in the G.A.N., but it is, I hope, enough to show that the British had a hand in the defence of Reims.

Order of Battle.

APPENDIX C.

German Divisions employed in the ATtack oN the 27/v/I8.

South of the Aisne.

XVth Corps.

Von Ilse

First line 213. 33 Res. 86. 7 Res.

Second Line 232. I2 Bav.

From Aisne to Vauxaillon.

LXVth Res. Corps First Line 52. 50. 5 Gds.

Von Schmettow. Second Line 103.

IVth Res. Corps. First Line 28. ro. Io Res.

Von Conta.

Second Line 36. 231 .

Ist Corps

First Line 33. $x$ Gds.

Von Winckler.

Second Line. I97. 28 Res.

VIIIth Res. Corps.

Von Wichuva.

In rear.

I3 Landw.

XXVth Res. Corps.

Von Lavisch.

First Line 37. I13.

Second Line 9. 47 Res.

First Line 5. 6. 6 Res. Bav.

Second Line $5 \mathrm{r}$ Res.

Vauxaillon to Oise.

VIIth Corps. First line 24r. I4 Res. 21 I.

Von François. Second Line 14. 
480 HOW THE BRITISH HELPED IN THE DEFENCE OF REIMS

\section{APPENDIX D.}

German Divisions in Attack on Viese Armée.

West of Reims, 15/vii/r8. I7 Divisions.

$\begin{array}{cc}\text { Original Line. } & \text { Brought up for Attacks. } \\ 86 & 195 \\ 123 & 103 \\ \text { I2 Bav. } & 113 \\ 22 & 37 \\ 28 \text { Res. } & \text { I Gd. } \\ \text { Io Ldw. }{ }^{1} & 2 \mathrm{Gd} . \\ & 200 \\ & \text { 10 } \\ & \text { ro Res. } \\ & 23 \\ & 36\end{array}$

Put in later.

$\frac{50}{I}$ (also made attack east of Reims).

APPENDIX E.

German Order of Battle for Attack on IVieme Armée, r5/Vil/r8.

From East to West. 20 Divisions.

Front Line.

33 Res. $^{2}$

88

I Bav.

2 Bav.

Grds. Cav, on Ft.

I

239

I99

Gds. Erz.

26

3 Gds.

I5 Bav.

$203^{2}$

238
Reserve. $228^{2}$ $30^{2}$ 7 Res. ${ }^{2}$

I9 Res. ${ }^{2}$

$80^{2}$ 
A.

Order of Battle of the Vitène Armée on the 27th May, I9I8, TOGETHER WITH RESERVES AVAILABLE IN THE G.A.N. AREA.

From East to West. In Line.

$45^{\mathrm{ieme}}$ Division.

IXth Corps, 2Ist, 8th, 50th Divisions.

25th Division in Corps Reserve.

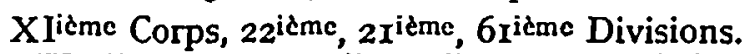

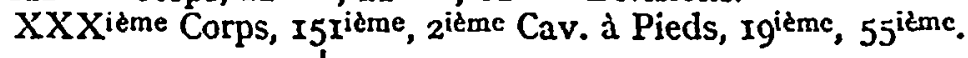

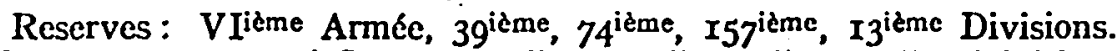

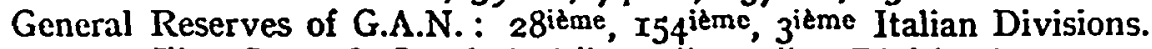
Iieme Corps de Cavaleric (I ${ }^{\text {ième }}, 4^{\text {ième }}, 5^{\text {ième Divisions). }}$

B.

Order of Battle of the IVieme Armé, ifth July, igi8.

From East to West.

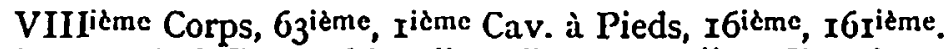

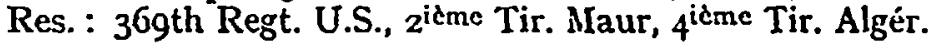

XXIiłme Corps, $43^{\text {ième }}, 13^{\text {ième }}, 170^{\text {teme }}$.

Res. : 42nd U.S.

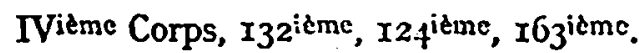

Res. : $7^{\text {ieme. }}$

Army Rescrves: $133^{\text {ì̀me }}, 52^{\text {ième }}, 4^{\text {ì̀me }}, 9^{\text {ì̀me }}, 27^{\text {ièmc }}$.

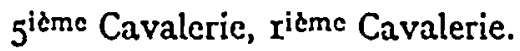

Order of Battle of the Vieme Armée, i4th July, 1918.

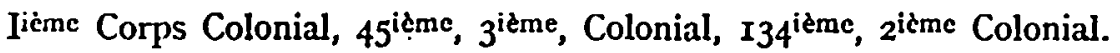
Res. : $7^{\text {ième. }}$

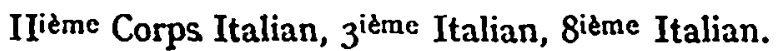

Res. : I2oième.

Viènno Corps, $40^{\text {iène, }} 8^{\text {ic̀nc. }}$

Res. : Io ième Colonial.

Army Rescrves : Ioieme, $77^{\mathrm{ième}}, 3^{\mathrm{i} \mathrm{imc}}$ Cavalerie. 
Order of Battle of the Virems Armée, r4th July, 9918.

III'ième Corps, $5^{\text {ìme }}, 125^{\text {ième. }}$

Res. : $55^{\text {th }}$ Bde. U.S.

XXXVIIIième Corps, 3rd U.S., $39^{\text {irme. }}$

Res. : 56th Bde. U.S.

Ist Corps U.S., 26th U.S., I67ime.

Res. : and U.S.

VIlième Corps, $164^{\text {ième }}, 47^{\text {ième. }}$

Res. : 8th Bde. U.S.

IIième Corps, $2^{\text {ième }}, 33^{\text {ième }}$

Res. : I68ieme, 7 th Bde. U.S.

Army Reserves : $73^{\text {ième }}, 4^{\text {ième}, ~} 20^{\text {ìme }}$.

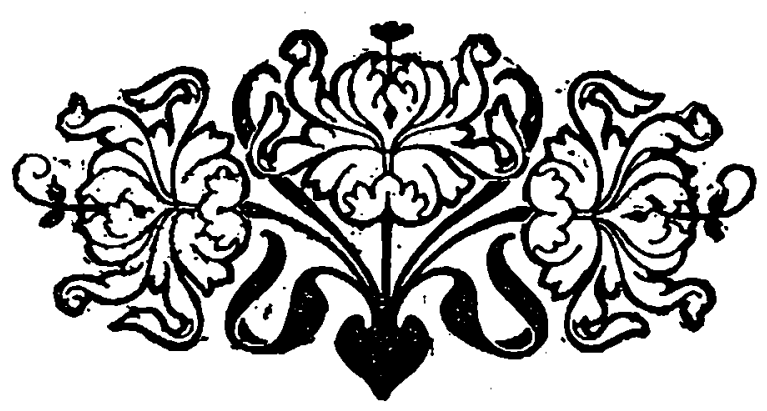

